\title{
No contribution of angiotensin-converting enzyme $(A C E)$ gene variants to severe obesity: a model for comprehensive case/control and quantitative cladistic analysis of $A C E$ in human diseases
}

\author{
Christopher G Bell ${ }^{*}, 1,9$, David Meyre ${ }^{2}$, Enrico Petretto ${ }^{3}$, Claire Levy-Marchal ${ }^{4}$, \\ Serge Hercberg ${ }^{4}$, Marie Aline Charles ${ }^{5}$, Cliona Boyle ${ }^{1}$, Jacques Weill ${ }^{6}$, Maïte Tauber ${ }^{7}$, \\ Charles A Mein ${ }^{8}$, Timothy J Aitman ${ }^{3}$, Philippe Froguel ${ }^{1,2}$ and Andrew J Walley ${ }^{1}$ \\ ${ }^{1}$ Genomic Medicine, Hammersmith Hospital, Imperial College London, London, UK; ${ }^{2}$ Centre National de la Recherche \\ Scientifique, UMR 8090-Institute of Biology, Pasteur Institute, Lille, France; ${ }^{3}$ Cardiovascular and Metabolic Disorders, \\ MRC Clinical Sciences Centre, Hammersmith Hospital, Imperial College London, London, UK; ${ }^{4}$ INSERM U457, Robert \\ Debre Hospital, Paris, France; ${ }^{5}$ INSERM U258-IFR69, Villejuif, France; ${ }^{6}$ Pediatric Endocrine Unit, Jeanne de Flandre \\ Hospital, Lille, France; ${ }^{7}$ INSERM U563, Children's Hospital, Toulouse, France; ${ }^{8}$ Bart's and the London Genome Centre, \\ Queen Mary's School of Medicine, London, UK; ${ }^{9}$ Haematology and Genetics, Prince of Wales Hospital, Sydney,
}

New South Wales, Australia

Candidate gene analyses are often inconclusive owing to genetic or phenotypic heterogeneity, low statistical power, selection of nonfunctional SNPs, and inadequate statistical analysis of the genetic architecture. Angiotensin-converting enzyme (ACE) is involved in adipocyte growth and function and the ACE-processed angiotensin II inhibits adipocyte differentiation. Associations between body mass index (BMI) and ACE polymorphisms have been reported in general populations, but the contribution to severe obesity of this gene, which is located under an obesity genome-scan linkage peak on $17 q 23$, is unknown. ACE is one of the most studied genes and markers responsible for variation in circulating ACE enzyme levels have been extensively characterised. Eight of these variants were genotyped in 1054 severely obese cases and 918 nonobese controls, as well as 116 nuclear families from the genome scan $(n=447)$, enabling the known clades to be inferred. Qualitative analysis of individual single-nucleotide polymorphisms (SNPs), haplotypes, clades, and diploclades demonstrated no significant associations $(P<0.05)$ after minimal correction for multiple testing. Quantitative analysis of clades and diploclades for BMI, waist-to-hip ratio, or ZBMI in children were also not significant. This rigorous, large-scale study of common, well-defined, severe polygenic obesity provides strong evidence that functionally relevant sequence variation in $A C E$, whether it is defined at the level of SNPs, haplotypes, or clades, is not associated with severe obesity in French Caucasians. Such a study design exemplifies the strategy needed to clearly define the contribution of the ACE gene to the plethora of complex genetic diseases where weak associations have been previously reported.

European Journal of Human Genetics (2007) 15, 320-327. doi:10.1038/sj.ejhg.5201754; published online 13 December 2006

Keywords: angiotensin-1 converting enzyme; single nucleotide polymorphism; obesity; body mass index; genetic association; cladistic analysis

*Correspondence: Dr CG Bell, Haematology and Genetics, Prince of Wales Hospital, High Street, Randwick, Sydney, New South Wales 2031, Australia. Tel: +61 293829169; Fax: +61 293829116;

E-mail: Christopher.Bell@sesiahs.health.nsw.gov.au

Received 30 June 2006; revised 26 October 2006; accepted 26 October 2006; published online 13 December 2006
Introduction

Obesity has become a major public health issue globally and has significantly contributed to increasing morbidity and mortality owing to type II diabetes and cardiovascular diseases such as hypertension, coronary artery disease, and 
congestive heart failure. ${ }^{1,2}$ Although the modern 'obesogenic' environment has a strong influence, there is compelling evidence for genetic susceptibility to common polygenic obesity and even more for the metabolic and vascular complications of obesity. ${ }^{3}$ In this regard, genetic variation in genes expressed in adipose tissue contributes to an increased risk of obesity-associated type II diabetes. ${ }^{4-6}$ In fact, the adipocyte is now seen as a potent autocrine and endocrine cell secreting many bioactive peptides, including angiotensin II. $^{7}$

The renin-angiotensin system (RAS) is a master regulatory system in human physiology. It synchronizes blood volume, arterial pressure, and cardiac and vascular function. Angiotensin-converting enzyme (ACE), which catalyses the formation of the bioactive peptide angiotensin II from angiotensin I, plays an integral part in cardiovascular homeostasis owing to its key role in the RAS. ${ }^{8}$ ACE and the RAS are known to be involved in adipocyte growth and metabolism. ${ }^{9,10}$ Furthermore, recent studies have demonstrated that angiotensin II inhibits adipocyte differentiation and promotes myocytic lipid deposition. ${ }^{11}$ Conversely, inhibiting the RAS reverses these effects ${ }^{12}$ and RAS blockers, in particular ACE inhibitors, have been shown to protect hypertensive subjects from the development of type II diabetes. ${ }^{13}$ Moreover, angiotensin (AT1) receptor blockers activate PPAR-gamma activity ${ }^{14}$ and adiponectin secretion, ${ }^{15}$ and these effects may explain their beneficial effect on insulin resistance. As adipose expansion is tightly correlated with deleterious features of the metabolic syndrome such as hypertension, the RAS and ACE could be involved in both the development of obesity and in the metabolic and vascular changes associated with this condition. ${ }^{16}$

Variation of the plasma concentration of ACE is one of the most well known examples of causative genetic variation within a locus and has been extensively studied owing to its vital physiological role. Associations have been proposed with various cardiac phenotypes ${ }^{17,18}$ as well as Alzheimer's disease ${ }^{19}$ and extreme physical endurance. ${ }^{20}$ Initially, the Alu repeat insertion/deletion (I/D) polymorphism of intron 16 was investigated, but further single-nucleotide polymorphism (SNP) analysis was hindered by the extensive linkage disequilibrium (LD) within the region. ${ }^{21,22}$ Therefore, a cladistic analytical strategy using haplotypic information as well as genotypes has been developed that utilises the ancestral recombination event that occurred within the gene and coalesces the variants into major clades. ${ }^{23,24}$

Two studies have recently proposed a direct association between obesity and polymorphisms within the ACE gene. Firstly, in an Italian longitudinal prospective cardiac outcome study, the $\mathrm{D} / \mathrm{D}$ allele of the I/D polymorphism was associated with larger increases in weight gain in aging males, and showed higher incidence in those that were overweight. $^{25}$ Secondly, in a Swedish study utilising SNPs and cladistic analysis, an association was found with obesity phenotypes in a cohort ascertained for various risk factors for myocardial infarction. ${ }^{26}$ Although both these studies were enriched for subjects with increased weight owing to their selection criteria, they were not specifically gathered for the obesity phenotype. The average body mass index (BMI) of participants in the Italian study was $26.9 \mathrm{~kg} / \mathrm{m}^{2}$ with a comparison made in 21 and $47 \%$ of the individuals who were defined as abdominally obese or overweight, respectively and range of BMI was $18.8-37 \mathrm{~kg} / \mathrm{m}^{2}$, therefore including no individuals who would qualify as morbidly obese. In the Swedish study, the mean BMI of cases ( \pm standard deviation) was $26.5( \pm 0.16)$ and 26.8 $( \pm 0.34) \mathrm{kg} / \mathrm{m}^{2}$ in men and women, respectively.

In a genome scan that we performed previously in a population of severely obese French Caucasians, one suggestive linkage was found at chromosome 17q23.3q25.1, with a maximal LOD score of 3.16 at $90.63 \mathrm{cM}^{27}$ The microsatellite marker D17S944 from that study was located closest to the peak of linkage. The ACE gene is situated within this peak region and is approximately $118 \mathrm{kbp}$ telomeric of D17S944, thus making it an excellent positional and biological candidate for severe obesity.

This present study has been performed in phenotypically extreme cases (adult cases mean $\mathrm{BMI}=45.4 \mathrm{~kg} / \mathrm{m}^{2}$, child cases ZBMI $>97$ th percentile) in order to strengthen the genetic component of the trait and to specifically focus on obesity and not other elements of the metabolic syndrome. As $A C E$ has been extensively studied in European populations, including French Caucasians, ${ }^{21}$ seven SNPs were selected for the analysis (Figure 1), to include those proposed as being responsible for variation in ACE levels (rs4459609, rs4291, rs4343, and rs4363) as well as spanning the gene and enabling the known clades to be inferred..$^{28-30}$ The I/D polymorphism was also analysed as this variant was used in the study of Italian subjects. ${ }^{25}$

\section{Methods \\ Subjects}

Subjects were all French Caucasians and were recruited using a multimedia campaign run by the Centre National de la Recherche Scientifique in collaboration with the Department of Nutrition of the Paris Hôtel-Dieu Hospital, the Institut Pasteur de Lille and in the Department of Pediatric Endocrinology of Jeanne de Flandres Hospital as well as the Toulouse Children's Hospital. For this study, a cohort of 548 unrelated severely and morbidly obese adults (average BMI $46.64 \mathrm{~kg} / \mathrm{m}^{2}, 82.0 \% \mathrm{BMI} \geqslant 40 \mathrm{~kg} / \mathrm{m}^{2}$ ), and 506 unrelated obese children (mean age $=9.96$ with a BMI $>97$ th percentile for age and sex) were used giving a total of 1054 cases. All subjects had been previously screened for MC4R mutations. In addition, 382 (out of a total of 447) individuals were genotyped for TDT analysis. These were from the 109 pedigrees used for the severe obesity genome 


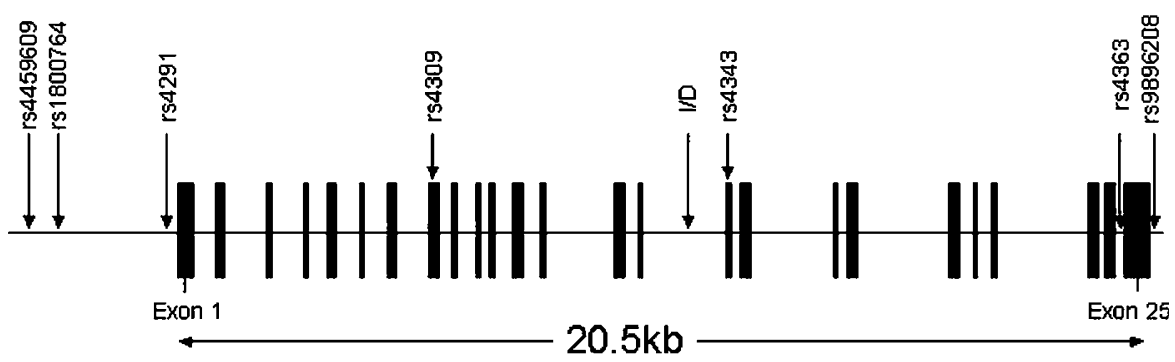

Figure 1 Diagram of the ACE gene with exons indicated with black boxes and SNPs and the I/D polymorphism location shown with arrows.

scan that located the suggestive linkage at chromosome $17 q 23.3-q 25.1 .^{27}$ The remaining 65 subjects had been already genotyped as they were included as part of the case group.

A total of 918 nonobese, nondiabetic adult subjects were utilised as controls for the association study. These comprised three groups, all being French Caucasians: the Fleurbaix Laventie Ville Sante (FLVS) study (72 males, 141 females; BMI: mean: $22.15 \mathrm{~kg} / \mathrm{m}^{2}$; standard deviation (SD): 1.69; age: mean: 42.22; SD: 4.52;), ${ }^{31}$ the Haguenau cohort (174 males, 191 females; BMI: mean: 21.27; SD: 2.00; age: mean: 23.17; SD: 3.85) were gathered from maternity registry data for a study investigating the adult outcome of those born small or appropriate for gestation age gathered from the north-east of France, with only the latter used here as controls, ${ }^{32}$ and the SUVIMAX ${ }^{33}$ (Supplementation en Vitamines et Minéraux Antioxidant) study cohort (103 males, 237 females; BMI: mean: 22.08; SD: 1.93; age: mean: 49.25; SD: 6.45) population in which regular weight measurements were taken so those who had never been obese during the eight-year course of the study were chosen. Subject phenotype information is shown in Supplementary Table S1.

The genetic study was approved by the Ethical Committee of the Hotel Dieu in Paris and CHRU in Lille. Phenotyping for BMI was performed as described previously. ${ }^{34}$ For children the $\mathrm{Z}$ score of their BMI was calculated (ZBMI) for comparison. Waist-to-Hip ratio (WHR) was calculated by dividing the circumference at the waist at the level of the umbilicus by the hip circumference at the level of the iliac crests.

\section{DNA isolation}

Genomic DNA was extracted from peripheral blood cells using PURE-GENE D50K DNA isolation kits (Gentra Systems).

\section{Genotyping}

The SNPs were genotyped using the Sequenom MassARRAY $^{\circledR}$ platform as described previously ${ }^{35}$ (http://www. sequenom.com). Plates were considered successful if $>75 \%$ of genotypes could be called and there was no significant deviation from Hardy-Weinberg equilibrium $(P>0.05)$.
Any plate or assay that failed on the Sequenom platform was genotyped using Taqman assay technology (ABI) using the $7900 \mathrm{HT}$, as described previously, ${ }^{36}$ and was required to pass the same plate success parameters.

The $A l u$ I/D variant was genotyped using the previously published method of Rigat et $\mathrm{al}^{8}$ scaled down to a $5 \mu$ l final reaction volume. Fragments were run out on a $2 \%(\mathrm{w} / \mathrm{v})$ agarose gel with a $100 \mathrm{bp}$ ladder (Gibco BRL, UK) to determine the presence of the $490 \mathrm{bp}$ insertion or $190 \mathrm{bp}$ deletion fragments. Each PCR plate was again required to fulfil the above success parameters. All details of primers used and reaction details for these methods are available from the authors.

\section{Statistics}

Frequencies were calculated and analysed using the SPSS statistical package version 12.0.0 (SPSS Inc). The $\chi^{2}$ test was performed, testing all cases against all controls as well as adult and children separately against the control group. This was performed using allele and genotype frequencies. Genotype frequencies were then analysed using dominant and recessive models. The dominant model compared the combined group of the heterozygotes and homozygotes for the rare allele with the homozygotes for the common allele, and the recessive model compared the homozygote rare allele group versus the rest. To confirm that there was no difference between the three groups of controls, allele, and genotype frequencies for each group were also compared by the $\chi^{2}$ test. Haplotypes were constructed using all seven SNPs and the I/D polymorphism using the program PHASE 2.1. ${ }^{37}$ Those that had missing data for any of the individual genotypes were removed from this analysis, giving a total of 1389 individuals. Linkage disequilibrium was calculated using HaploXT from the result for all cases and controls and graphically displayed using the programme GOLD. ${ }^{38}$

The common clades were inferred using the method of Katzov et al. ${ }^{26}$ This involved using the genotypes for rs1800764 and rs4343 to assign the possible cladotypes A, $\mathrm{B}$, and $\mathrm{C}$. These are genotypes (for rs1800764 followed by rs4343) of TA, CG, and TG for the respective clades A, B and C. Processing the data from these two SNPs with PHASE v2.1 was used to infer the clades. ${ }^{37}$ Diploclades, that is, the 
clades assigned to the two chromosomes for each individual, were then assigned based on the determined clades. Clade and diploclade frequencies were then compared using the $\chi^{2}$ test. Dominant models utilising clade A (the Alu insertion including clade) versus combinations of the B and $\mathrm{C}$ clades were also tested using the $\chi^{2}$ test.

The quantitative traits of BMI, WHR, and ZBMI (the latter in children only) were then analysed after first being normalised (assessed by the Kolmogorov-Smirnov test in SPSS v12.0.0 (SPSS Inc)). Using the clade and diploclade definitions, these quantitative traits were then compared by analysis of variance (ANOVA) (using SPSS v12.0) for total cases versus controls and for groups defined by sex and age. Separate analysis was performed in the male and female division of the cohorts for allele and genotype frequency (Supplementary Table S2), clade analysis by total, adult and child (Supplementary Table S4), clade by age $\geqslant 50$ years (Supplementary Table S5), quantitative analysis of BMI by clade (Table 4), and diploclade analysis (Supplementary Table S6). The genome-scan families were only analysed for SNP and polymorphism associations with BMI using the quantitative transmission disequilibrium test (QTDT). ${ }^{39,40}$ This was because testing the quantitative trait was expected to be significantly more powerful than for the qualitative trait as it would utilise those moderate overweight individuals in this subset analysis. QTDT includes exact estimation of $P$-values for analysis of small samples and non-normal data. For alleles with a significant $P$-value in QTDT, empirical significance levels were calculated using 1000 Monte-Carlo permutations. The orthogonal model of association was also considered, ${ }^{41}$ which allows analysis of families of any size, with or without parental genotypes. All the QTDT analyses were performed on the $\log _{10}$-transformed BMI data with sex, age, hypertension and type II diabetes affection status as covariates, which generally affect BMI variation significantly.

\section{Results}

The genotype frequencies of the three control collections of French Caucasians were compared and no significant differences were found; hence the control groups were pooled for comparison with the cases. Adult controls were used for case-control comparison in both the adult and child extreme obesity cohorts because these are superior to matched age group controls as they have received longer environmental exposure, but remain non-obese. Although age cohort effects can be postulated, no significant difference was found between any of the adult and child allele frequencies $(P<0.05$, data not shown). Duplicate samples from one representative repeated sample batch (301 samples) were found to have a $0.66 \%$ discordant call rate, which is similar to that expected of high-quality genotyping under ideal conditions of $\sim 1 \%$. ${ }^{42}$ Allele and genotype numbers and percentages are displayed in Table 1. Case-control analysis was performed between the total case group as well as the separate child and adult groupings compared to the control group. No significant results were obtained for allele frequency. For genotype frequencies the only significant individual $P$-value was obtained for the I/D genotype in males only $(P=0.02$, data not shown for sexsplit). For haplotype analysis, a total of 54 haplotypes were inferred by PHASE 2.1 with four having a frequency above $5 \%$. These showed no significant variation when compared between cases and controls (Table 2), adults and controls, or children and controls (data not shown). The two most frequent haplotypes were completely divergent, carrying a different allele at each variant site. The linkage disequilibrium of these variants was visualised using the GOLD software (Supplementary Figure S1) using the $r^{2}$ statistic and is consistent with previous observations of an ancestral recombination event between SNPs rs4291 and rs4309 with two blocks of strong LD either side of this breakpoint. ${ }^{23}$ We additionally inferred haplotypes with PHASE 2.1 for these two separate regions of strong LD (the first three and later four SNPs plus the ID variant). No significant differences in haplotype frequencies for total, adult or child versus control groups were found for either block (data not shown).

Cladistic analysis revealed no significant difference between total cases and controls, or when split into adult and child groupings (Table 3). Quantitative BMI analysis showed no significant difference either between mean BMI for total cases (Table 4) or when divided by sex (data not shown). Diploclade analysis was not significant for frequencies between total cases and controls (Table 5) or for any dominant model of the insertion containing clade $\mathrm{A}$ versus clades $\mathrm{B}$ and $\mathrm{C}$ combined (data not shown). Analysis after division by sex and between child and adult groups revealed one significant result for the subset of male children versus controls for the AA diplocladotype $(P=0.024$, data not shown). No differences were found if the groups were subdivided on the basis of age $\geqslant 50$ years for the total group or for male or female subsets (data not shown). Quantitative results for diploclades are shown in Table 6. Diploclade was shown not to influence mean BMI values within the case group nor within the controls. WHR was not statistically significantly associated in total cases, or in male- or female- only cases (data not shown). The ZBMI score within the affected children was also not associated with the diploclades, even when subdivided by sex (data not shown). Because of the intentionally low variance in the control samples, normalisation of these data was not possible; however, analysis of the unmodified data returned no significant $P$-values (data not shown).

Analysis of the genome scan families using the QTDT showed nominal association $(P=0.034)$ of BMI with rs4309, but this failed to achieve the empirical threshold 
Table 1 SNP case-control analysis for obesity

\begin{tabular}{|c|c|c|c|c|c|c|c|c|}
\hline \multirow[b]{2}{*}{ SNP } & \multirow[b]{2}{*}{ Subject group } & \multirow[b]{2}{*}{ Genotyping \% } & \multirow[b]{2}{*}{ HWE P value } & \multicolumn{3}{|c|}{ Genotype numbers (\%) } & \multirow[b]{2}{*}{ Allele $\mathrm{P}$ value } & \multirow[b]{2}{*}{ Genotype P value } \\
\hline & & & & 11 & 12 & 22 & & \\
\hline rs4459609 $(1=A, 2=C)$ & $\begin{array}{l}\text { Controls } \\
\text { Adults } \\
\text { Children }\end{array}$ & $\begin{array}{l}91 \\
93.7 \\
95.7\end{array}$ & $\begin{array}{l}0.344 \\
0.988 \\
0.866\end{array}$ & $\begin{array}{l}296(34.9) \\
175(33.6) \\
163(34.1)\end{array}$ & $\begin{array}{l}402(47.5) \\
252(48.5) \\
238(49.7)\end{array}$ & $\begin{array}{r}149(17.6) \\
93(17.9) \\
77(16.1)\end{array}$ & $\begin{array}{l}0.690 \\
0.934\end{array}$ & $\begin{array}{l}0.869 \\
0.670\end{array}$ \\
\hline rs1800764 $(1=\mathrm{T}, 2=\mathrm{C})$ & $\begin{array}{l}\text { Controls } \\
\text { Adults } \\
\text { Children }\end{array}$ & $\begin{array}{l}94.9 \\
94.4 \\
93.5\end{array}$ & $\begin{array}{l}0.95 \\
0.735 \\
1\end{array}$ & $\begin{array}{ll}238 & (27.3) \\
137 & (26.1) \\
124 & (26.4)\end{array}$ & $\begin{array}{l}429(49.3) \\
252(48.2) \\
236(50.4)\end{array}$ & $\begin{array}{l}203(23.3) \\
134(25.6) \\
108(23.1)\end{array}$ & $\begin{array}{l}0.275 \\
0.871\end{array}$ & $\begin{array}{l}0.599 \\
0.919\end{array}$ \\
\hline rs4291 $(1=\mathrm{A}, 2=\mathrm{T})$ & $\begin{array}{l}\text { Controls } \\
\text { Adults } \\
\text { Children }\end{array}$ & $\begin{array}{l}95 \\
79.5 \\
95.9\end{array}$ & $\begin{array}{l}0.132 \\
0.845 \\
0.95\end{array}$ & $\begin{array}{l}316(36.1) \\
158(35.8) \\
172(35.8)\end{array}$ & $\begin{array}{l}412(47.1) \\
217(49.2) \\
234(48.8)\end{array}$ & $\begin{array}{r}146(16.7) \\
66(14.9) \\
74(15.4)\end{array}$ & $\begin{array}{l}0.736 \\
0.806\end{array}$ & $\begin{array}{l}0.668 \\
0.781\end{array}$ \\
\hline rs4309 $(1=\mathrm{C}, 2=\mathrm{T})$ & $\begin{array}{l}\text { Controls } \\
\text { Adults } \\
\text { Children }\end{array}$ & $\begin{array}{l}94.6 \\
93.4 \\
93.9\end{array}$ & $\begin{array}{l}0.251 \\
0.973 \\
0.528\end{array}$ & $\begin{array}{ll}330 & (38.0) \\
204 & (39.3) \\
175 & (37.3)\end{array}$ & $\begin{array}{l}393(45.3) \\
240(46.3) \\
216(46.1)\end{array}$ & $\begin{array}{r}144(16.6) \\
74(14.3) \\
78(16.6)\end{array}$ & $\begin{array}{l}0.333 \\
0.868\end{array}$ & $\begin{array}{l}0.526 \\
0.961\end{array}$ \\
\hline$I / D(D=1, I=2)$ & $\begin{array}{l}\text { Controls } \\
\text { Adult } \\
\text { Children }\end{array}$ & $\begin{array}{l}85.8 \\
88.9 \\
90.9\end{array}$ & $\begin{array}{l}0.995 \\
0.257 \\
0.37\end{array}$ & $\begin{array}{l}288(36.5) \\
194(39.4) \\
161(35.5)\end{array}$ & $\begin{array}{ll}381 & (48.4) \\
216 & (43.9) \\
208 & (45.9)\end{array}$ & $\begin{array}{r}118(15.0) \\
82(16.7) \\
84(18.5)\end{array}$ & $\begin{array}{l}0.745 \\
0.269\end{array}$ & $\begin{array}{l}0.276 \\
0.261\end{array}$ \\
\hline rs4343 $(G=1, A=2)$ & $\begin{array}{l}\text { Controls } \\
\text { Adult } \\
\text { Children }\end{array}$ & $\begin{array}{l}95 \\
93.9 \\
96.1\end{array}$ & $\begin{array}{l}0.971 \\
0.888 \\
0.996\end{array}$ & $\begin{array}{l}283(32.6) \\
179(34.3) \\
149(31.1)\end{array}$ & $\begin{array}{l}428(49.3) \\
248(47.6) \\
238(49.7)\end{array}$ & $\begin{array}{r}157(18.1) \\
94(18.0) \\
92(19.2)\end{array}$ & $\begin{array}{l}0.621 \\
0.570\end{array}$ & $\begin{array}{l}0.759 \\
0.805\end{array}$ \\
\hline $\operatorname{rs} 4363(G=1, A=2)$ & $\begin{array}{l}\text { Controls } \\
\text { Adult } \\
\text { Children }\end{array}$ & $\begin{array}{l}90 \\
89.8 \\
91.5\end{array}$ & $\begin{array}{l}0.145 \\
0.538 \\
0.662\end{array}$ & $\begin{array}{ll}270 & (32.6) \\
175 & (35.1) \\
151 & (33.0)\end{array}$ & $\begin{array}{l}389(47.1) \\
230(46.2) \\
217(47.5)\end{array}$ & $\begin{array}{r}167(20.2) \\
93(18.7) \\
89(19.5)\end{array}$ & $\begin{array}{l}0.306 \\
0.803\end{array}$ & $\begin{array}{l}0.583 \\
0.950\end{array}$ \\
\hline rs9896208 $(1=\mathrm{C}, 2=\mathrm{T})$ & $\begin{array}{l}\text { Controls } \\
\text { Adult } \\
\text { Children }\end{array}$ & $\begin{array}{l}90.4 \\
90.7 \\
94.7\end{array}$ & $\begin{array}{l}1 \\
0.993 \\
0.625\end{array}$ & $\begin{array}{ll}271 & (32.6) \\
157 & (31.2) \\
158 & (33.4)\end{array}$ & $\begin{array}{l}410(49.3) \\
247(49.1) \\
222(47.0)\end{array}$ & $\begin{array}{r}150(18.1) \\
99(19.7) \\
92(19.5)\end{array}$ & $\begin{array}{l}0.437 \\
0.869\end{array}$ & $\begin{array}{l}0.700 \\
0.693\end{array}$ \\
\hline
\end{tabular}

For the genotypes, frequent allele homozygotes $=11$, heterozygotes $=12$, and rare allele homozygotes $=22$. These frequencies were compared using the $\chi^{2}$ test for allele frequency and codominant genotype models. Dominant and recessive models were also nonsignificant (data not shown). Genotyping success percentage (\%) and Hardy-Weinberg equilibrium (HWE) $P$-values also given.

Table 2 Haplotype analysis

\begin{tabular}{lccc}
\hline Haplotype & $\begin{array}{c}\text { Number of cases } \\
\text { (\%) }\end{array}$ & $\begin{array}{c}\text { Number of controls } \\
\text { (\%) }\end{array}$ & P-value \\
\hline 11122221 & $484(32.4)$ & $412(32.0)$ & 0.639 \\
22211112 & $427(28.6)$ & $358(27.9)$ & 0.400 \\
22211111 & $117(7.8)$ & $105(8.2)$ & 0.637 \\
11111111 & $76(5.1)$ & $69(5.4)$ & 0.464 \\
Rare $(<5 \%)$ & $389(26.1)$ & $341(26.5)$ & N/A \\
\hline
\end{tabular}

Comparison of the frequencies of the four common ( $>5 \%$ haplotype frequency) haplotypes for combined cases and controls. No significant result was obtained when the cases were split into adults and children (data not shown). $P$-value is displayed for the $2 \times 2 \chi^{2}$ test of one haplotype versus the rest.

for global significance of $P=0.008$ (1000 Monte-Carlo permutations) (Supplementary Table S7).

\section{Discussion}

The main result of the present study, using the latest available data on ACE functional SNPs, is the absence of
Table 3 Cladistic analysis

\begin{tabular}{lccc}
\hline Clade & Number of cases (\%) & Number of controls (\%) & P-value \\
\hline A & $845(43.1)$ & $726(43.0)$ & 0.946 \\
B & $886(45.2)$ & $763(45.1)$ & 0.947 \\
C & $229(11.7)$ & $201(11.9)$ & 0.837 \\
\hline
\end{tabular}

Comparison of numbers of cases and controls for each clade versus the others using a $2 \times 2 \chi^{2}$ test. Analysis of the two adult and child sets of cases separately versus controls was also non-significant (data not shown).

any kind of replication of association with obesity phenotypes previously described in other European cohorts. In order to achieve this result, a study strategy was implemented based upon the most rigorous approach to evaluating the contribution of $A C E$ variants to complex, polygenic obesity. The most extreme phenotype was used, that is, severe morbid obesity, to enrich for possible genetic effects, together with a large number of samples. SNPs were chosen for genotyping using information from both the published literature and the public databases to ensure 
analysis of well-established known functional $A C E$ variants. Statistical analysis included a comprehensive examination of frequency differences between cases and controls using alleles, genotypes, haplotypes, diplotypes, cladotypes, and diplocladotypes. We believe that this approach has conclusively ruled out any genetic association of $A C E$ variants with obesity in French Caucasians and exemplifies the meticulous approach that must be taken in examining any gene for a role in a complex genetic disease.

With respect to the previously published associations, in contrast to the ID polymorphism finding from the Italian population, $^{25}$ we found the I/I genotype to be more, not less, prevalent in the case group, although this was not significant after adjustment for multiple testing. We found no differences for SNPs rs4343 or rs1800764 for BMI between any case and control grouping, in contrast to

Table 4 Quantitative analysis of BMI by clade for all adult cases and subdivided by sex

\begin{tabular}{lccc}
\hline & \multicolumn{3}{c}{ Mean case BMI $( \pm S D)$} \\
Clade & Total & Males & Females \\
\hline A & $45.63( \pm 7.87)$ & $46.93( \pm 9.11)$ & $45.29( \pm 7.40)$ \\
B & $45.37( \pm 7.87)$ & $45.65( \pm 7.47)$ & $45.29( \pm 7.59)$ \\
C & $44.89( \pm 8.44)$ & $47.10( \pm 10.99)$ & $44.20( \pm 7.40)$ \\
Total & $45.43( \pm 7.79)$ & $46.32( \pm 8.60)$ & $45.17( \pm 7.52)$ \\
$P$-value & 0.585 & 0.625 & 0.397 \\
\hline
\end{tabular}

$P$-value is displayed for ANOVA test on normalised BMI.

Table 5 Diplocladistic analysis

\begin{tabular}{|c|c|c|c|}
\hline Diploclade & Number of cases (\%) & Number of controls (\%) & P-value \\
\hline $\mathrm{AA}$ & $187(19.2)$ & $152(18.0)$ & 0.546 \\
\hline$A B$ & $380(38.8)$ & $335(39.6)$ & 0.7 \\
\hline$A C$ & $93(9.5)$ & $88(10.4)$ & 0.53 \\
\hline $\mathrm{BB}$ & $201(20.5)$ & 168 (19.9) & 0.726 \\
\hline$B C$ & $102(10.3)$ & $90(10.7)$ & 0.813 \\
\hline CC & $17(1.7)$ & $12(1.4)$ & 0.707 \\
\hline
\end{tabular}

Diploclades for each individual were analysed using a $2 \times 2 \chi^{2}$ test for diploclade versus all other diploclades. the earlier finding reported in a subset of Swedish male patients. ${ }^{26}$ In the diploclade analysis, the only significant $P$-value result was for the AA diplocladotype in male children, which was not significant if any correction for multiple testing was made. This association in children is also opposite to that reported by the Italian I/D study, which found an age effect in the deletion carrying individuals, as the diploclade AA represents homozygosity for the insertion carrying allele. No quantitative differences were found in children for ZBMI in relation to the AA diploclades, either overall or for male children only. No differences were found for any of the quantitative measures of obesity such as BMI and WHR in the adult groups or ZBMI in the affected children for either clade or diploclade. Overall, this French Caucasian severe obesity study found no statistically significant association between genetic markers and qualitative or quantitative obesity traits when divided up by sex and/or age groupings after any modest correction for multiple testing.

The possible reasons for the discrepancy between our study and others are many. We estimate that we have $80 \%$ power to detect an effect with a relative risk as low as 1.26 for the deletion polymorphism homozygote (nominal significance of $P<0.05$ ), which was found to have a relative risk of 2.34 in the Italian study. ${ }^{43}$ These power calculations, however, depend on $100 \%$ genotyping success rate. With an approximate success rate of $90 \%$, the power would decrease to $76 \%$. This would also be sufficient to detect such low relative risk gene variants as the recently described (and replicated) type II diabetes susceptibility gene TCF7L2, with a relative risk value of $1.45 .^{44}$ Undetected stratification is unlikely after extensive statistical analysis of these samples in previous studies. Although we used two case cohorts (adults and children) and three control cohorts, we were unable to detect any evidence of differences in allele frequencies that may reflect stratification. Conflicting genetic results can also occur when there are subtle SNP frequency differences between populations or when functional SNPs differ among human populations. No significant difference was found between the control frequencies for the ID polymorphism in the Italian report and this study's French

Table 6 Quantitative trait analysis by diploclades in adult and child cases

\begin{tabular}{|c|c|c|c|c|c|c|}
\hline Diploclades & Average BMI adult cases & $\pm S D$ & Average $Z B M I^{\mathrm{a}}$ child cases & $\pm S D$ & Average $W H R^{\mathrm{a}}$ adult cases & $\pm S D$ \\
\hline AA & 46.40 & 8.3 & 4.350 & 1.288 & 0.950 & 0.124 \\
\hline$A B$ & 44.70 & 6.8 & 4.597 & 1.174 & 0.954 & 0.117 \\
\hline$A C$ & 46.03 & 9.9 & 4.495 & 1.169 & 0.947 & 0.109 \\
\hline BB & 46.25 & 8.1 & 4.377 & 1.198 & 0.962 & 0.137 \\
\hline$B C$ & 43.68 & 7.3 & 4.557 & 1.338 & 0.922 & 0.087 \\
\hline $\mathrm{CC}$ & 45.12 & 5.8 & 5.464 & 2.053 & 0.925 & 0.097 \\
\hline$P$-value & 0.235 & & 0.269 & & 0.794 & \\
\hline
\end{tabular}

BMI analysis for adults and ZBMI analysis for children, and WHR analysis in adult cases only. $P$-value is displayed for ANOVA for normalised values. ${ }^{\mathrm{a}} \mathrm{BMI}=$ body mass index; $\mathrm{WHR}=$ waist-to-hip ratio. 
sample. Differences were found with the comparison for SNP and diploclade frequencies with the Swedish controls; however, it is likely that the French and Italian populations are more similar, as there are well-known examples of geographical variations in allele frequencies within Europe, for example, the delta-32 CCR5 polymorphism. ${ }^{45}$

In addition, there is the often-neglected issue of the careful ascertainment of cases, especially when 'easy' phenotypes such as weight and height are available in most human cohorts recruited for any kind of medical research. Given the current strong environmental pressure for the development of moderate overweight (affecting almost two-thirds of the US population ${ }^{46}$ ), our data strongly suggest the need to focus on the most extreme phenotypes (in our case BMI $>40 \mathrm{~kg} / \mathrm{m}^{2}$, which affects $0.6 \%$ of the French population ${ }^{47}$ compared to $4.7 \%$ in the $\mathrm{US}^{46}$ ) in order to define the effect of genes on morbid forms of obesity, that is, those having a large impact on mortality and morbidity.

$A C E$ is one of the few human genes to have been submitted to extensive trans-ethnic SNP analysis, elucidating the ancestral SNP gene structure and identifying most functional SNPs (ie those that modulate enzyme levels in the blood). We systematically genotyped the seven SNPs plus the I/D variant, ensuring that those SNPs most convincingly reported to be functional were included. ${ }^{28-30}$ Thus, we maximised our chances of detecting an association between a known functional $A C E$ variant and obesity. It is possible that the association of $A C E$ variants with adiposity found in cohorts recruited for cardiovascular outcomes, and not for obesity, reflects a potential influence of $A C E$ SNPs on the complications of overweight rather than on obesity per se.

Obesity is a very heterogeneous condition with major environmental influence. In this respect, it is likely that for a large proportion of humans with moderate fat excess, obesity is not a disease (eg a consequence of a primary biological disturbance at the level of the individual), but rather a physiological condition due to environmental 'obesogenic' pressure affecting the entire population. This study does not rule out the possibility that the overweight state, rather than morbid obesity, may interact with $A C E$ to promote disease development, as recently shown for adiponectin/ACDC gene $\mathrm{SNPs}^{5}$ but it is clear that $A C E$ does not play any role in well-defined clinical obesity or obesity-associated traits in French Caucasian subjects.

Rigorous, large-scale study of common functionally relevant sequence variation in the $A C E$ gene defined at the level of SNPs, haplotypes, or clades provides strong evidence that this gene is unlikely to contribute to the risk for severe obesity in a European population. In published genetic studies, there is a recognised inflated type 1 error because the trend is to report only significant findings, where significant does not necessarily mean true findings. Reporting negative results is also important because this will help other research groups to improve/refine their study design and the definition of phenotypic criteria. It will also make future meta-analysis more likely to give a true result. In this respect, our well-defined study design exemplifies the strategy needed to clearly define the contribution of important genes, and the $A C E$ gene in particular, to the whole range of complex genetic diseases and traits.

\section{References}

1 Must A, Spadano J, Coakley EH, Field AE, Colditz G, Dietz WH: The disease burden associated with overweight and obesity. JAMA 1999; 282: 1523-1529.

2 Calle EE, Rodriguez C, Walker-Thurmond K, Thun MJ: Overweight, obesity, and mortality from cancer in a prospectively studied cohort of US adults. N Engl J Med 2003; 348: 1625-1638.

3 Bell CG, Walley AJ, Froguel P: The genetics of human obesity. Nat Rev Genet 2005; 6: 221-234.

4 Meyre D, Bouatia-Naji N, Tounian A et al: Variants of ENPP1 are associated with childhood and adult obesity and increase the risk of glucose intolerance and type 2 diabetes. Nat Genet 2005; 37: 863-867.

5 Vasseur F, Helbecque N, Lobbens S et al: Hypoadiponectinaemia and high risk of type 2 diabetes are associated with adiponectinencoding (ACDC) gene promoter variants in morbid obesity: evidence for a role of ACDC in diabesity. Diabetologia 2005; 48: 892-899.

6 Osawa H, Yamada K, Onuma $H$ et al: The G/G genotype of a resistin single-nucleotide polymorphism at -420 increases type 2 diabetes mellitus susceptibility by inducing promoter activity through specific binding of Sp1/3. Am J Hum Genet 2004; 75: 678-686.

7 Ahima RS, Flier JS, Vasseur F et al: Adipose tissue as an endocrine organ. Trends Endocrinol Metab 2000; 11: 327-332.

8 Rigat B, Hubert C, Alhenc-Gelas F, Cambien F, Corvol P, Soubrier F: An insertion/deletion polymorphism in the angiotensin Iconverting enzyme gene accounting for half the variance of serum enzyme levels. J Clin Invest 1990; 86: 1343-1346.

9 Darimont C, Vassaux G, Ailhaud G, Negrel R: Differentiation of preadipose cells: paracrine role of prostacyclin upon stimulation of adipose cells by angiotensin-II. Endocrinology 1994; 135: 2030-2036.

10 Jones $\mathrm{BH}$, Standridge MK, Moustaid N: Angiotensin II increases lipogenesis in 3T3-L1 and human adipose cells. Endocrinology 1997; 138: 1512-1519.

11 Sharma AM, Janke J, Gorzelniak K, Engeli S, Luft FC: Angiotensin blockade prevents type 2 diabetes by formation of fat cells. Hypertension 2002; 40: 609-611.

12 Furuhashi M, Ura N, Takizawa $\mathrm{H}$ et al: Blockade of the reninangiotensin system decreases adipocyte size with improvement in insulin sensitivity. J Hypertens 2004; 22: 1977-1982.

13 Scheen AJ: VALUE: analysis of results. Lancet 2004; 364: 932-933, author reply 935 .

14 Schupp M, Janke J, Clasen R, Unger T, Kintscher U: Angiotensin type 1 receptor blockers induce peroxisome proliferator-activated receptor-gamma activity. Circulation 2004; 109: 2054-2057.

15 Clasen R, Schupp M, Foryst-Ludwig A et al: PPARgammaactivating angiotensin type- 1 receptor blockers induce adiponectin. Hypertension 2005; 46: 137-143.

16 Jones BH, Standridge MK, Taylor JW, Moustaid N: Angiotensinogen gene expression in adipose tissue: analysis of obese models and hormonal and nutritional control. Am J Physiol 1997; 273: R236-R242.

17 Cambien F, Poirier O, Lecerf L et al: Deletion polymorphism in the gene for angiotensin-converting enzyme is a 
potent risk factor for myocardial infarction. Nature 1992; 359: 641-644.

18 Schunkert H: Polymorphism of the angiotensin-converting enzyme gene and cardiovascular disease. J Mol Med 1997; 75: $867-875$.

19 Kehoe PG, Russ C, Mcllory S et al: Variation in DCP1, encoding ACE, is associated with susceptibility to Alzheimer disease. Nat Genet 1999; 21: 71-72.

20 Montgomery HE, Marshall R, Hemingway $\mathrm{H}$ et al: Human gene for physical performance. Nature 1998; 393: 221-222.

21 Villard E, Tiret L, Visvikis S, Rakotovao R, Cambien F, Soubrier F: Identification of new polymorphisms of the angiotensin Iconverting enzyme (ACE) gene, and study of their relationship to plasma ACE levels by two-QTL segregation-linkage analysis. Am J Hum Genet 1996; 58: 1268-1278.

22 Rieder MJ, Taylor SL, Clark AG, Nickerson DA: Sequence variation in the human angiotensin converting enzyme. Nat Genet 1999; 22: $59-62$.

23 Farrall M, Keavney B, McKenzie C, Delepine M, Matsuda F, Lathrop GM: Fine-mapping of an ancestral recombination breakpoint in DCP1. Nat Genet 1999; 23: 270-271.

24 Keavney B, McKenzie CA, Connell JM et al: Measured haplotype analysis of the angiotensin-I converting enzyme gene. Hum Mol Genet 1998; 7: 1745-1751.

25 Strazzullo P, Iacone R, Iacoviello L et al: Genetic variation in the renin-angiotensin system and abdominal adiposity in men: the Olivetti Prospective Heart Study. Ann Intern Med 2003; 138: 17-23.

26 Katzov H, Bennet AM, Kehoe P et al: A cladistic model of ACE sequence variation with implications for myocardial infarction, Alzheimer disease and obesity. Hum Mol Genet 2004; 13: $2647-2657$.

27 Bell CG, Benzinou M, Siddiq A et al: Genome-wide linkage analysis for severe obesity in French Caucasians finds significant susceptibility locus on chromosome 19q. Diabetes 2004; 53: $1857-1865$.

28 Zhu X, McKenzie CA, Forrester T et al: Localization of a small genomic region associated with elevated ACE. Am J Hum Genet 2000; 67: 1144-1153.

29 Zhu X, Bouzekri N, Southam L et al: Linkage and association analysis of angiotensin I-converting enzyme (ACE)-gene polymorphisms with ACE concentration and blood pressure. Am J Hum Genet 2001; 68: 1139-1148.

$30 \operatorname{Cox} \mathrm{R}$, Bouzekri N, Martin S et al: Angiotensin-1-converting enzyme (ACE) plasma concentration is influenced by multiple ACE-linked quantitative trait nucleotides. Hum Mol Genet 2002; 11: 2969-2977.

31 Lafay L, Basdevant A, Charles MA et al: Determinants and nature of dietary underreporting in a free-living population: the Fleurbaix Laventie Ville Sante (FLVS) Study. Int J Obes Relat Metab Disord 1997; 21: 567-573.
32 Jaquet D, Collin D, Levy-Marchal C, Czernichow P: Adult height distribution in subjects born small for gestational age. Horm Res 2004; 62: 92-96.

33 Hercberg S, Preziosi P, Briancon S et al: A primary prevention trial using nutritional doses of antioxidant vitamins and minerals in cardiovascular diseases and cancers in a general population: the SU. VI.MAX study - design, methods, and participant characteristics. SUpplementation en VItamines et Mineraux AntioXydants. Control Clin Trials 1998; 19: 336-351.

34 Bell CG, Meyre D, Samson C et al: Association of melaninconcentrating hormone receptor $15^{\prime}$ polymorphism with earlyonset extreme obesity. Diabetes 2005; 54: 3049-3055.

35 Sauer S, Gut IG: Genotyping single-nucleotide polymorphisms by matrix-assisted laser-desorption/ionization time-of-flight mass spectrometry. I Chromatogr B Analyt Technol Biomed Life Sci 2002; 782: 73-87.

36 Livak KJ, Marmaro J, Todd JA: Towards fully automated genomewide polymorphism screening. Nat Genet 1995; 9: 341-342.

37 Stephens M, Donnelly P: A comparison of bayesian methods for haplotype reconstruction from population genotype data. Am J Hum Genet 2003; 73: 1162-1169.

38 Abecasis GR, Cookson WO: GOLD - graphical overview of linkage disequilibrium. Bioinformatics 2000; 16: 182-183.

39 Spielman RS, Ewens WJ: A sibship test for linkage in the presence of association: the sib transmission/disequilibrium test. Am J Hum Genet 1998; 62: 450-458.

40 Abecasis GR, Cardon LR, Cookson WO: A general test of association for quantitative traits in nuclear families. Am J Hum Genet 2000; 66: 279-292.

41 Abecasis GR, Cookson WO, Cardon LR: Pedigree tests of transmission disequilibrium. Eur J Hum Genet 2000; 8: 545-551.

42 Hattersley AT, McCarthy MI: What makes a good genetic association study? Lancet 2005; 366: 1315-1323.

43 Purcell S, Cherny SS, Sham PC: Genetic Power Calculator: design of linkage and association genetic mapping studies of complex traits. Bioinformatics 2003; 19: 149-150.

44 Grant SF, Thorleifsson G, Reynisdottir I et al: Variant of transcription factor 7-like 2 (TCF7L2) gene confers risk of type 2 diabetes. Nat Genet 2006; 38: 320-323.

45 Libert F, Cochaux P, Beckman G et al: The deltaccr5 mutation conferring protection against HIV-1 in Caucasian populations has a single and recent origin in Northeastern Europe. Hum Mol Genet 1998; 7: 399-406.

46 Flegal KM, Carroll MD, Ogden CL, Johnson CL: Prevalence and Trends in Obesity Among US Adults, 1999-2000. Jama 2002; 288: $1723-1727$.

47 ObEpi: Le surpoids et l'obésité en France: enquête épidémiologique réalisée dans un échantillon représentatif de la population française, adulte et enfant. Une enquête INSERM/Institut Roche de l'Obésité/SOFRES 2003; 1-5.

Supplementary Information accompanies the paper on European Journal of Human Genetics website (http://www.nature.com/ejhg) 